\title{
The Pelvic-Pulmonary Connection
}

\author{
Neil S. Cherniack \\ New Jersey Medical School, Newark, N.J., USA
}

There are lots of ways women differ from men besides the most obvious. Most of these differences are the results of the release of ovarian hormones. Estrogen seems to protect against Alzheimer's disease, coronary artery occlusion, and osteoporosis. All of these problems become more prominent in menopausal women in the absence of estrogen replacement treatment. Estrogen seems to exert its effect by attachment to receptors in tissues and ultimately by changes at the nuclear level [1-3].

In this issue of Respiration, Eterović et al. [4] discuss differences in breathing and in the respiratory system of men and women. As others have shown, women tend to hyperventilate in the luteal phase of the menstrual cycle. The cause of this seems to be estrogen action both at the carotid body and in the brain (perhaps at the hypothalamus). The findings of Eteroviæ et al. [4] confirm this. In addition, obstructive sleep apnea in women is rare until after the menopause, and the upper airway muscles may behave differently in men and women [5].

In the above-mentioned and in an earlier paper, Eterović et al. [4, 6] propose that a connective tissue disorder causes prolapse of the pelvic organs and may also cause lung disease. The collagen content of biopsies of the vaginal and uterine walls is reduced in women with prolapse, and collagen turnover rates are greater [7]. The skin of women with prolapsed pelvic organs also shows collagen abnormalities, and hypermobility of the joints is also more common in those women suggesting that if there are defects in collagen, the abnormalities are widespread. In their earlier paper, the same authors showed decreased vital capacity and flow rates in women with prolapsed pelvic organs. In the current paper, these women have more hypoxemia perhaps due to a collagen problem in the lungs which leads to altered mechanical function and gas ex- change. Estrogen, directly and indirectly through its effects on relaxin release, can affect connective tissue. Levels of progesterone were higher in the follicular phase in women with prolapse, but the effect this difference might have on connective tissue is obscure.

The hypothesis of a connective tissue disorder that produces pelvic prolapse, lung disease, and hyperextensibility of the joints is intriguing and probably deserves more study. But another explanation has not been excluded. In their earlier paper, they found that cough was common in women with pelvic prolapse [6]. Airway or lung disorders that cause chronic cough could also have led to the pelvic prolapse. More studies will reveal which is the correct idea.

\section{References}

1 Regensteiner JG, Woodward WD, Hagerman DD, Weil JV, Pickett CK, Bender PR, Moore LG: Combined effects of female hormones and metabolic rate on ventilatory drives in women. J Appl Physiol 1989;66:808813.

2 Baylis DA, Milhorn DE: Central neural mechanisms of progesterone action: Application to the respiratory system. J Appl Physiol 1992;73:393404.

3 Hanhart B, Pickett CK, Weill JV, Moore LG: Influence of pregnancy and carotid body neural output responsiveness to hypoxia in cats. J Appl Physiol 1989;67:797-803.

4 Eterović D, Strinić T, Dujić Z, Boban, M: Blood gases and sex hormones in women with and without genital descensus. Respiration 1999;66:400406.

5 Popovic RM, White DP: Upper airway muscle activity in normal women Influence of hormonal status. J Appl Physiol 1998;84:1055-1062.

6 Strinić T, Eterović D, Dujić Z, Marković V, Tocilj J: Spirometric disorders in women with genital descensus. Acta Obstet Gynecol Scand 1997;76: 879-883.

7 Rechberger T, Donica H, Baranowski W, Jakowicki J: Female urinary stress incontinence in terms of connective tissue biochemistry. Eur J Obstet Gynecol Reprod Biol 1993;49:187-191.

\begin{tabular}{ll}
\hline KARGER & ( ) 1999 S. Karger AG, Basel \\
Fax +4161306 1234 & 0025-7931/99/0665-0396\$17.50/0 \\
$\begin{array}{l}\text { E-Mail karger@karger.ch } \\
\text { www.karger.com }\end{array}$ & $\begin{array}{l}\text { Accessible online at: } \\
\text { http://BioMedNet.com/karger }\end{array}$
\end{tabular}

Neil S. Cherniack, MD

Office of the Dean, UMDNJ-New Jersey Medical School

$185 \mathrm{v}$ South Orange Avenue

Newark, NJ 07103-2714 (USA)

Tel. +1 973972 7937, Fax +1 9739727104 